\title{
Beyond binary identity politics? Ethnic, cultural and gendered othering in Feo Aladağ's Die Fremde
}

\section{Cordula Böcking}

To cite this article: Cordula Böcking (2014) Beyond binary identity politics? Ethnic, cultural and gendered othering in Feo Aladağ's Die Fremde, Studies in European Cinema, 11:3, 212-222, DOI: $10.1080 / 17411548.2014 .972670$

To link to this article: https://doi.org/10.1080/17411548.2014.972670

曲 Published online: 14 Jan 2015.

Submit your article to this journal $\pi$

III Article views: 247

Q View related articles ๘

View Crossmark data \lceil 


\title{
Beyond binary identity politics? Ethnic, cultural and gendered othering in Feo Aladağ's Die Fremde
}

\author{
Cordula Böcking* \\ Department of German, School of Modern Languages, Literatures and Cultures, Maynooth \\ University, Ireland
}

\begin{abstract}
This paper examines how Feo Aladağ's Die Fremde (2010) simultaneously perpetuates and undermines stereotypes of Turkish-German gender constructs and in doing so engages in a form of othering that, drawing on a long-established discourse in Turkish-German cinema, conflates the Other in terms of gender with the Other in terms of ethnicity and culture. Lauded for eschewing well-worn clichés of traditional Turkish-Muslim patriarchy, Die Fremde represents diasporic identity construction and with it clashes of culture among first- and second-generation Turkish migrants in Germany. Does Aladağ manage to escape the binary economies implied by tropes such as the oppressed Turkish woman, the German saviour and the Turkish oppressor; and do the filmic devices she uses subvert a ghettoization of those values that deviate from the Leitkultur of the majority culture? With the stigmatization of Muslim men emerging as the flipside of female oppression, Die Fremde, I will argue, goes beyond re-creating earlier stereotypes and instead shines a critical light on how such othering is an integral part of German national post-war narrative.
\end{abstract}

Key words: Turkish-German film; gender; ethnic stereotypes; bicultural identity; patriarchalism; diaspora

The very title of Feo Aladağ's Die Fremde (When We Leave, Aladağ, 2010), a film that represents diasporic identity construction and with it clashes of culture among first- and second-generation Turkish migrants in Germany, succinctly encapsulates the notion of otherness. 'Die Fremde' has a double meaning, lost in the English version of the title, When We Leave': it can denote the (female) foreigner/stranger as well as the foreign/ strange land. In its first meaning, 'die Fremde' is the film's Turkish-German protagonist Umay, who, depending on perspective, might be regarded as a stranger in either German or Turkish society. In addition, 'die Fremde' evokes the feeling of alienation associated with living in a country not one's own, which could be seen to refer to Umay's parents' experience of Germany just as much as to Umay's attitude towards Turkey. ${ }^{2}$

Traditional registers have configured self and Other as synonymous with 'civilized' and 'barbarian', and portrayed them as natural entities, constituting Western European modernity as the centre, as famously analysed, for example, in Edward Said's Orientalism, which conceptualizes colonizer/colonized relationships by uncovering notions of Occidental superiority over Oriental Others (e.g., Said 1978, 3). The colonized is constructed by the colonizer as the 'Other' who is alien, yet also visible and known. Orientalism produces uneven knowledge, using reductive formulae and inventing 'collective identities for large numbers of individuals who are actually quite diverse'

*Email: cordula.boecking@nuim.ie 
(Said 1978, xxii), privileging the position of the Western legislator in the process. The challenge for European postcolonial films has long been to question such paradigms, rethinking traditional relations between centre and periphery and initiating a dialogue between the two in the process. This dialogue has resulted in a move away from Eurocentrism, revealing the hybridic nature of Europe's multicultural, multiethnic, diasporic communities, and showing Europe itself to be a fluid, highly mobile, even provisional concept (cf. Morgan-Tamosunas and Rings 2003, 14).

Given that Turkish-German artists, such as writer Emine Sevgi Özdamar, routinely refer to Turkey as one of the 'new colonies' the Germans created on their home territory (see, e.g., Horrocks and Kolinsky [1996, 52f]), it seems legitimate to regard Turkey, although not a colony in the traditional sense, as a colonized entity in this context. And although she is a native Austrian (the Turkish Aladağ is her married name), Feo Aladağ might not fall into the category of postcolonial filmmakers by birth: categorizing films depicting migrant experience 'based on the filmmakers' biographical credentials' would, as Berghahn puts it, 'in fact, be paradoxical, given that many diasporic family films challenge the primordial categories of bloodline and descent' $(2013,48)$. Avoiding such biographical fallacies, the subject-matter depicted rather than the filmmaker's biography must thus count as the relevant criterion for viewing this film as part of a certain tradition of filmic representations of othering.

In what follows, I will examine how Aladağ's When We Leave simultaneously perpetuates and undermines stereotypes of Turkish-German constructs of gender, culture and ethnicity. As critics have pointed out, the 'colonization of the mind', both European and ex-colonized, is still visible 'in the continuing prominence of dichotomous images of the Western Self and the formerly colonized Other' (Morgan-Tamosunas and Rings 2003, 12f). Perhaps unsurprisingly, then, Aladağ both engages in and exposes a form of othering that draws on a long-established discourse in Turkish-German cinema. Ethnic and gendered otherness are traditionally aligned, as can be observed in stereotypical equations of the 'foreign' female with attributes of victimhood, and the 'foreign' male with attributes of violence, such as in the cliché of the sauvage (Morgan-Tamosunas and Rings 2003, 13). Katherine Pratt Ewing, in her ethnographic study Stolen Honor (2008) analysing the discursive construction of public culture and the nation in Germany, draws attention to the fact that both victimized female and oppressing male are presumed to be in need of protection or guidance by paternalistic constructs of Western society with their promise of democracy and liberation. Investigating gender constructs can therefore be a fruitful line of enquiry in order to explore whether a film resists the inequitable binaries of an orientalizing discourse. Does Aladağ manage to resist or escape the binary economies that tropes present in her work, and in parts of the earlier corpus of Turkish-German film - such as the oppressed Turkish woman, the German saviour and the Turkish oppressor imply; and do the filmic devices she uses subvert a ghettoization of those values that deviate from the hegemonic Leitkultur of the majority culture? Or, does When We Leave represent a regression into an oldergeneration cinema that casts migrant experience and identity in rigid essentialist, rather than discursive and performative, terms $?^{3}$

Aladağ was inspired to make her feature film after Amnesty International had asked her to direct a short film on honour killing as part of its 'Stop Violence against Women' campaign. ${ }^{4}$ The film draws on real-life events, namely the honour killing in Berlin of Hatun Sürücü in 2005. Sürücü, a woman of Turkish-Kurdish origin, was pulled out of a well-integrated high school in Berlin by her father and sent to Turkey to marry a cousin. Having divorced a few years later, she returned to Berlin with her son, started training 
as an electrical engineer, and was subsequently killed by her brothers, who objected to the fact that she had begun living, as they saw it, 'like a foreigner' (cited in Ewing [2008, 156]).

When We Leave follows these real-life events. Protagonist Umay, raised in Germany by Turkish parents, has moved to Istanbul with her Turkish husband Kemal, but when his abusive behaviour becomes too much for her to take, she decides to return to Berlin with her young son, Cem. This move is not met with support from her family, who believe that Umay had no right to leave Kemal and at the very least should return Cem to his father. Umay, however, refuses to bow to tradition. As a result, her family breaks off contact with her as they consider her to have brought dishonour on them. As Umay's independence grows (she takes a job, studies for her Abitur, takes a flat, starts going out with a German man), her family and the Turkish community at large become increasingly concerned by what they view as her transgressive behaviour. The male relatives decide to kill Umay in a bid to restore the family honour. Tragically, in the only substantial divergence from the historical case, this accidentally results not in Umay's, but in Cem's death.

Aladağ's very choice of title suggests, in its multivalency, that her work goes beyond purely black-and-white allocations of blame. She has said in interviews that her motivation in making this film was to portray the universal desire to be loved and accepted as one is, and that it was precisely not her intention to point the finger at anyone (Aladağ 2010a). It is this empathy for the perpetrator side that has gained her film admiration: When We Leave received a mostly positive reception in the German press, ranging from well-worn cliché (allusions to Arabian Nights) to comparison with a central work of the German canon, in the shape of Fontane's Effi Briest (Buss 2010); cf. also Berghahn [2013, 133]). ${ }^{5}$ While most reviewers as well as some scholarly critics seemed to agree that Aladağ had managed to steer clear of a stereotypical portrayal of the perpetrators, ${ }^{6}$ stereotype and prejudice were exactly what coloured the perception inherent in some reviews - such as the one in cinema magazine, which lauded the film's depiction of its characters' 'tragic dependence on religious constraints', ${ }^{7}$ which is somewhat incongruous given that religion is never once evoked as a motivation for the killing.

There has long been a tradition in Turkish-German cinema of 'defining peripheries and centres and constructing images of self and other' (Hake and Mennel 2012, 1). Turkish-German cinema, understood here as cinema depicting Turkish-German experience, has displayed a particular sensitivity towards national belonging and ethnic embodiment, attempting, in more recent decades, to destabilize discourses of social realism and identity politics and challenging simplistic binaries such as native/foreign, home/ abroad and tradition/modernity (cf. 1). These binaries were initially asserted by the first wave of films processing the experience of Turkish migrant workers who started coming to Germany as part of a purposely recruited cheap workforce just over 50 years ago, following the 1961 labour recruitment agreement between Germany and Turkey. Among the first films to address this experience are Tevfik Başer's $40 \mathrm{~m}^{2}$ Deutschland/40 $\mathrm{m}^{2}$ Germany (1986) and Hark Bohm's Yasemin (1988), both of whom work heavily with the template of the quasi-criminal Turkish male (husband, father) versus the oppressed Turkish younger woman (wife, daughter), with Bohm throwing in the German male saviour for good measure. The binary poles of oppression and sympathy are crucial in these early films, characterizing a stance that Göktürk $(2000,66)$ has described as the 'a social worker's perspective'. Films such as these are very much a depiction of binary identity politics of East versus West, portraying an on-screen conflict between a (Turkish) minority 
culture from whose enclaves of tradition the more 'enlightened' Turkish protagonists try to escape on the one hand, and a (German) majority culture to which individual Turkish protagonists are trying to adapt on the other. This problematic ideological stance invokes a Manichean cultural opposition 'whereby the social norms of the West, such as a largely secular way of life, the right to self-determination and women's equality, are pitted against the traditional values of Islamic societies, which are depicted as archaic and inhumane' (Berghahn 2010, 243; cf. also Göktürk 2010).

This era, represented primarily by German directors, was followed by a new generation of Turkish-German filmmakers who put their own stamp on the notion of the cinéma $d u$ métissage. It is a cohort represented perhaps most prominently by Fatih Akın, who subverted the stereotypes of the Turkish-German female as victim and her male counterpart as oppressor and turned them on their head, in films like Gegen die Wand/Head-On (2004), Im Juli /In July (2000) and Auf der anderen Seite/The Edge of Heaven (2007), all of which are stories about hybrid identities and the pleasures and challenges afforded by them. A similarly successful recent subgenre is the multicultural comedy, such as Yasemin Şamdereli's Almanya - Willkommen in Deutschland/Almanya - Welcome to Germany (2011), characterized by a humorous and frothy approach to the depiction of cultural and generational difference.

When We Leave has nothing in common with these recent trends, some of which can be seen as output of what Huggan has termed a veritable 'alterity industry' (2001, vii), portraying Turkish-German characters as hip, cosmopolitan urbanites unfettered by the cultural traditions of their fatherland. Instead, Aladağ presents us with a vision that appears on first sight to reiterate or reify old stereotypes, according to which German culture is shorthand for modern/good, while Turkish culture is configured as old-fashioned/evil. The film starts with a juxtaposition of life on the outskirts of Asian Istanbul and in Berlin. By having the protagonist return from Turkey to her native Germany, Aladağ goes against the grain of typical depictions of Turkish-German mobility, which involve either a move 'back to the roots', to the land of the fathers, or a westward journey away from one's country of birth and towards 'enlightenment'. While family life in Turkey is as claustrophobic as the viewer schooled on traditional representations of Turkish-German experience might expect, the journey westward does not spell an increase in personal freedom for Umay. For what emerges is that life within the confines of the Turkish family is strikingly similar in Turkey and in Germany.

It is because Umay no longer wants to endure the violence that characterizes family life in Istanbul that she moves to Berlin, only to find herself in a duplicated version of the earlier scenario. There are strong parallels with regard to lighting, furniture, even seating arrangements, which correspond to a similar scenario of oppression. The patriarchal structures appear unchanged as the protagonist moves westward; in both instances, the patriarch heads the table, gives orders, and expects obedience, while subservient women are restricted and abused by their male relatives. Rather than depicting the move to Germany as liberating, Aladağ presents an instance of doubling, suggesting that Umay's family lives life in Berlin as if they were still in Turkey. In its criticism, but also in its stereotypical depiction of the Turkish patriarchy, the opening scenarios of Die Fremde is aptly captured in Naficy's description of the much earlier $40 \mathrm{~m}^{2}$ Germany, where 'the claustrophobic chronotope of home is relocated to the host society, isolating and confining primarily women' $(2001,193){ }^{8}$

The dark, confined spaces of the family flat are subsequently contrasted with encounters on the outside, where relief from oppression is provided not only in the open spaces of the city, but also in the enclosed yet public spaces of institutions such as 
hospital and police station. Such encounters take place between the conflicted protagonist and her Western or Westernized friends or well-meaning officials (the exception being the meeting between Umay and her mother in the park, where Halime, as carrier of the migrant culture, implores Umay to see sense and, on her refusal to do so, disowns her, perhaps suggesting the incompatibility of the two worlds of repression on the one hand, liberation on the other). Thus Umay escapes to the light-flooded park to meet her friend Atife, a blonde Turkish woman who is assimilated to the degree that she smokes, drinks, parties and enjoys the sexual freedom of a German woman. This setting is in notable contrast to the urban wasteland in Istanbul where Umay earlier meets up with her sympathetic female cousin, Zeynep. Likewise, the playground in the women's shelter in Berlin where she is temporarily resident is pictured as a sunny oasis, while the catering business where she works is characterized by a marked brightness, the dazzling light reflected and intensified by the white kitchen uniforms. ${ }^{9}$ That contrasts are a defining aesthetic and structural principle in this film is obvious not only in the juxtaposition of domestic and enclosed versus public spaces, but also in the contrast between 'Turkish' and 'Westernized' interior spaces. A comparison of Atife's or Umay's flat with that of Umay's parents, or the party scene at Atife's with the festivities celebrating Umay's sister's wedding, throws up strong contrast between light and darkness (reinforced through the absence of windows in the latter instances) on a physical level, while the party's inclusivity is in sharp opposition to the hostile attitude that the wedding celebrants display towards the ostracized Umay.

Escape from the oppression of the Turkish-marked spaces beckons further through Umay's relationship with German colleague Stipe. A dinner date represents a form of eating together that is directly opposed to the one that typified her family life previously. Instead of expecting Umay to serve food to the males, her companion expresses concern for her own well-being, asking whether she is hungry and generally addressing her directly. On the same date, Stipe takes Umay through Berlin on his bike and, from an elevated vantage-point, shows her a vista overlooking a train station that captures the possibility and openness of a life lived without fear or societal constraints. And so we witness a shift from the family-defined claustrophobic spaces of old to Umay moving freely through the city. When she eventually returns to her flat in the early morning, walking across a bridge smiling in what could be a subtle reference to Emine Sevgi Özdamar's Die Brücke von Goldenen Horn/Bridge of the Golden Horn (1998), it becomes clear that mobility is linked to happiness and possibility. Yet although the bridge is a long-established and heavily contested symbol of bi-culturality, its significance here is without potency, which is fitting given the eventual failure to mediate between the two cultures that Umay finds herself experiencing.

So far, so clichéd. On the surface, Aladağ's film presents us with precisely the Eurocentric Turkish/German, Eastern/Western dichotomy prevalent in earlier Turkish-German films, according to which Germany and Turkey provide, both literally and metaphorically, open versus closed spaces, marked by pairs of mutually exclusive attributes such as liberal/oppressive and modern/traditional. When We Leave expresses this not only on the level of plot development, but also, in a somewhat heavy-handed way, through its mise-en-scène. This includes lighting - brightly lit versus dark interiors, open-air and nature settings versus confined spaces - and costume, such as white versus dark clothing (the 'angelic' Stipe in his white kitchen apparel notably contrasting with the darkclad 'evil' Mehmet). The dichotomy is also gendered in a rather rigid way: while some of the female Turkish characters, such as businesswoman Gül and Umay's free-spirited friend Atife, exhibit independence and liberal values, thus supplying potential role 
models, the film, quite shockingly, provides not a single genuinely positive example of Turkish masculinity: all the men portrayed, seemingly in thrall to the patriarchal order, eventually condone Umay's killing. Umay's younger brother, Acar, initially displays a more liberal mind-set; but he, too, turns against his sister once the community rejects them, although he is unable to carry out the shooting he has been ordered to do. Respite comes only from figures that are either female or non-Turkish - although the role of the mother, somewhat atypically, is not empowered when it comes to rescuing oppressed members of their community, as is often the case with maternal figures within diasporic communities (cf. Tarr 2010, 185; see, e.g., the mother in Ataman's Lola + Bilidikid/Lola + Billy The Kid (1999).

By having female Turkish figures adapt to Western values, the othering of the Turkish male is exacerbated further. Turkish men are other not only in relation to Turkish women, but also to German men. German men - from the police officers who 'rescue' Umay from her parents' flat, to Stipe who gives her emotional support, to the teacher who encourages her in the pursuit of higher education - appear as benign potential saviours, foregrounding the otherness that sets Turkish masculinity apart from the Western ideal and recalling the stereotype of the Turkish sauvage in need of guidance at the hands of the enlightened German, who is other vis-à-vis both members of his own ethnicity and members of his own gender.

Nevertheless, a closer look at the representation of male Turkish characters suggests that they are constructed differently from the stereotypical male oppressors of earlier films depicting Turkish migrant experience. Although When We Leave contains unapologetically violent males such as Umay's husband Kemal and her older brother Mehmet, Turkish men are characterized mostly by their paralysis in the face of societal demands, leaving them unable to talk or act, let alone take control of their destiny. While Umay's father Kader condones her husband's acts of violence and is seen to take orders from his own father, who is confined to a sick-bed in far-away Anatolia, he is conflicted throughout in his condemnation of his daughter until eventually his heart literally breaks when he has a heart attack, leading him to seek her forgiveness despite being unable to stop the events he has set in motion. Gramling $(2012,36)$ has remarked that Turks in Die Fremde are foreignized through silence, as in both Germany and Turkey, whether speaking German or Turkish, the speech of Turkish-marked characters in the film is always characterized by restraint or extreme emotion. However, it is important to note that this applies primarily to the male characters. There are numerous shots that show Kader (whose name means 'Fate') teary-eyed, speechless, helpless and struggling to accept what his community apparently perceives as the inevitable.

When Kader seeks guidance from his father in rural Turkey, not a single word is exchanged between the two. ${ }^{10}$ The father is portrayed as old and weak, recalling another stereotype that influences Western imaginings of the Turkish man: the work-shy Oriental. This suggests that the order he represents is about to become extinct - making it all the more baffling, to a Western audience, that Kader would choose to take his cue from him. Notably, the Turkish culture that informs Kader's thinking is shown here to be grounded in a rural setting - a far cry from the modern secular Turkey that is founded on a repudiation of the Ottoman Empire. This points to a culture clash that is not first and foremost a clash between an Islamic society and the liberal secular West, but [actually] one between rural and urban cultures' (Ewing 2006, 279), even though the rural values are carried over into the urban setting of Istanbul, and eventually to Berlin. Crucially, however, the absence of alternative male Turkish voices conceals the fact that 
this set of values is representative only of a subgroup of the Turkish population residing in Germany.

The male protagonists' fragility and inarticulateness culminates in the film's final scenes, where Kader and his sons appear utterly helpless in the face of the distant patriarch's decree that Umay must be killed. Their impotence manifests itself in different ways, from Acar punching furniture (1:38:16) to Mehmet crying (1:38:28) and Kader sitting impassively $(1: 37: 26)$. This helplessness is reinforced through instances of doubling, as when we see Acar watching from the bus in motionless horror as Mehmet is poised to murder their sister, and Mehmet crying uncontrollably after he has committed the deed. The conflictedness of these men - who, more than anything else, are portrayed as broken and incapable - is played out in the context of a discourse on masculinity made explicit early on when Kader, after humiliating a rebellious Acar by slapping him in the face, tells his son to behave like a man and chaperone his sister at all times (00:24:27-45).

Desire to control the female members of the family is one of the markers of both masculinity and otherness in Turkish men in the film, yet their ability to control is shown to be severely compromised. The first example of this occurs when the German police come to escort Umay, who has placed a rescue call, from her parents' flat (00:40:33-41:54). The officers display a patronizing attitude towards Mehmet and Kader, even though both display perfectly polite behaviour to begin with. From the point of view of the Aslans, this nocturnal visit represents an intrusion into their private space. Only too quick to categorically condemn the Turkish males as oppressors before they have even done anything to offend, the police officers as emissaries of the German state violate the Aslans' right to the sanctity of the home. Here, Umay's right to protection from abuse clash with her family's basic citizen rights, as listed in the German Grundgesetz [Constitution] (cf. Art. 13.1, 'The home is inviolable'). The police officers show a clear bias towards 'the oppressed woman' when they do not even ask to verify Umay's claims. Such violation of the Turkish males' rights is the first step in a process that leads them to feel disenfranchised, and nurtures aggression among them.

The process of abjection of the Turkish male is reinforced when a lawyer at the women's shelter where Umay has sought refuge orders her to break off any contact with her family (00:45:23). The men's gradual loss of control eventually erupts in violence when Mehmet and his friends show up at the refuge centre to assert their dominance. In the violent confrontation that ensues, Umay asks him whether 'this is supposed to prove [he's] a man?' (1:12:31). Feeling challenged in their masculinity, the men turn even more violent, confirming the notion of female oppression as a result of destabilized male identity (cf. Ewing 2006, 279). When Umay denounces kinship with her brother, stating, in response to the shelter warden's question, that she doesn't know who the men are, Mehmet, as prime representative of the violent Turkish male, is further humiliated, until violence finally escalates into murder at the end of the film.

The denial of kinship is reiterated when Atife prompts Umay to report Mehmet to the police (1:06:20-52). Umay objects that this is her family, to which Atife replies that her family consists of herself and her son only. While different ideas of family - Western nuclear versus Eastern extended - clash here, Umay is asked to take sides in a way that involves categorically casting off her family ties. The German state offers her protection (through police, shelter, lawyer), but in order to avail of it, she, too, must cast her family as abject (which, poignantly, is also what she is to them). She is urged to renounce any loyalties that are not compatible with the German ideal of personal freedom, as inscribed in the German constitution (cf. Art. 2.1, 'the right to freedom of 
personal development'). Values deviating from this tenet of the majority culture are being ghettoized, and the Western gaze's othering is extended even to the female protagonist herself; for example, when Atife expresses incomprehension at Umay's reluctance to report a member of her family to the police (1:06:35).

Unlike the fearsome patriarchs of earlier films, the male characters of Turkish extraction in When We Leave are portrayed as victims of their own crime nearly as much as its perpetrators. After the police 'invasion' of the family home and subsequent intervention by the German authorities propel them towards greater violence, they are shown to be helpless to the extent that they are unable to abstain from what is blatantly wrong not only from the perspective of the German characters, but ultimately also from their own, as indicated by the grief that accompanies their actions. Incapable of standing up to things they no longer believe in, they are caught between the radically opposing demands of two communities, unable even to verbalize any of these issues. Though not taking the perpetrators' side, the film portrays their helplessness in the face of societal obligations, and thus allows for a more nuanced picture than the one presented in the earlier, miserabilist 'social worker' cinema. Despite reverting to the conventions of an orientalizing discourse at times, and notwithstanding the fact that the incapable and inarticulate man could be viewed as another Orientalist cliché, Aladağ succeeds in depicting how these men are stigmatized by German society and how the 'host' society's readiness to other them exacerbates difference and drives them further into violence. This is most evident when the female protagonist is asked to take sides and corroborate such othering in order to access personal freedom as it is construed by the German state. Notably, as far as the official authorities are concerned, Umay's rights supersede those of her male relatives from the beginning - suggesting, perhaps, that the German constitution is not applied with the same rigour to every member of the population.

The Turkish community portrayed in When We Leave is a world apart from the hybrid-urban society of contemporary transnational film: the pleasures of hybridity and the normality of the global village are not an option for its protagonists. Umay has 'arrived' in Germany, she is integrated, works, benefits from state-funded childcare, studies towards higher education; in other words, she ticks all the boxes required of the strong female migrant - yet this is not enough: her efforts to lead an autonomous existence are thwarted by her family, as well as by her own reluctance to break with them and by German society's lack of understanding for this.

Aladağ's film is not duplicating the scenario of the 'ghetto' films of the 1970s and '80s, where immigrants live in segregation and where 'the Turkish woman' is portrayed as being without language, without rights and without possibilities for escape. Umay is not without language (although the film shows that mastering the language is no guarantee of integration, as the example of her brothers and father shows), or without rights (she has a German passport and is protected by German law), but she is nevertheless unable to escape the brutal customs of her family's culture. The male German saviour (in the various guises of policemen, teacher, boyfriend) is now being supported by the assimilated Turkish woman (Atife, Gül); but none of them, not even Umay herself, can save her from the fate meted out to her by her male Turkish relatives.

While women have the option to adopt liberal values, this does not necessarily save them from being oppressed by these men. ${ }^{11}$ As Tarr has noted, 'the patriarchal regulation of women's roles, women's bodies and women's sexuality has traditionally been crucial to the construction of both national and diasporic identities' $(2010,178 \mathrm{f})$. Western values such as freedom and education are apparently inaccessible to Turkish men, reprising the stereotype of the sauvage. ${ }^{12}$ Thus othering is gendered in a way that 
engages the old binaries. Katherine Pratt Ewing (2008) has argued that the stigmatization of Turkish males equals an abjection that is part of the German post-war national narrative - a narrative that sees itself as founded on democracy, freedom and liberalism. When We Leave evokes stereotypes of the majority culture's attitude towards a diasporic minority that are in keeping with this narrative: the film demonstrates how Muslim men, through being characterized as an embodiment of the non-democratic Other, are being rendered as abject in the name of upholding a 'democratic' German national imaginary. As shown earlier, it is in the context of protecting the constitutional rights of the Muslim woman that 'the culturally shaped masculinity of the Muslim man [can] be stigmatized without generating a repudiation of the act of stigmatization itself' (Ewing 2008, 227). The act of stigmatization is protected from criticism by the fact that the agencies representing the German state and its value system that engage in this act are consistently presented in a positive light. They are assigned protective spaces, configured as havens of freedom and equality; epitomized, for instance, in the immaculate hospital with its promise of healing and preservation of life, where Umay's father, having recently arranged for her death, receives treatment following his heart attack, and in the brightly lit police station where she reports her abusive brother while a policewoman casually strides down the staircase (1:30:41) in an unmistakable display of gender equality.

While such stark contrasts could be seen to speak precisely to the inequity generated by an orientalizing mindset, When We Leave does not merely reflect the workings of Orientalism, but rather exposes them, too, even if this is not achieved consistently. Although to some degree criticism of the film as conventional, even reactionary, is justified (cf., e.g., Yaren 2011, 59), Aladağ's work at times manages to transcend earlier stereotyping and instead shines a critical light on the mechanics of othering as part of contemporary German national narrative. ${ }^{13}$ This is particularly evident in those moments when the central character is forced to deny the Other in herself, as the part of her that is loyal to her family is othered by those subscribing to Western principles. The ideal of assimilation necessitates the ghettoization of values not conforming to the hegemonic majority culture. Specifically, this finds expression in the German and Germanized characters' inability to understand what is going on inside the Turkish family: the police who are involved twice to 'rescue' Umay from her family; the lawyer who insists on her strict detachment from the latter, exhorting her not to transgress the Bannmeile (protective area); the boyfriend who asks whether it would improve Umay's relationship with her family if he married her; and, last but not least, Atife, who demands that Umay report her family to the police. Their inability to comprehend her ties to her kin is complemented by Umay being cast as abject by her own family when she aligns herself with the state authorities protecting her rights.

When We Leave explores the cruel and absolute nature of othering by foregrounding the pressure placed on the bicultural protagonist to deny the Other within herself, while also focusing on the emotional and moral fragility that underscores manifestations of migrant masculinity. In this respect, Aladağ goes beyond the reification of simplistic binary orders and instead challenges the process of their creation, despite the occasionally somewhat heavy-handed symbolism, not to mention the melodramatic ending that might be read to insinuate, through third-generation Cem's death, the self-induced extinction of the Turkish male. By pointing to the failure to support integration as a deficiency located on both sides of the cultural divide that falls short of mutual acknowledgment of what might be termed a mutual Other, the film transcends a simplistic, black-and-white 'social worker approach' in favour of something more universal. 


\section{Notes}

1. Berghahn remarks that a dual perspective characterizes also the English film title, which 'draws attention to the conflicts arising from [...] dual and ambiguous attachments to two different localities' $(2013,132)$.

2. Incidentally, 'Fremde' is a highly literary term, which evokes, e.g., the topical quote from Goethe's Iphigenie auf Tauris, 'Kann uns zum Vaterland die Fremde werden?' (I, 2).

3. Gramling, somewhat harshly, perhaps, posits that Aladağ's film compels the presence of a certain agreement of the predicate, whose subject is the collectively imagined, young Muslim Turkish-German woman: 'The predicate to which this subject is made to agree is the inevitability and omnipresence of patriarchal violence toward each and every Muslim woman' $(2012,34)$.

4. For background information on honour killings, see Laviosa (2010).

5. Buss (2010), in his review of the film in Der Spiegel, likens When We Leave to the great German Gesellschaftsroman (society novel) Effi Briest on account of its treatment of the individual's conflict with society and its universal appeal as a realist milieu drama.

6. Cf., e.g., Berghahn, who states that When We Leave eschews the polarization between the victimized daughter and the patriarchal perpetrator $(2013,131)$.

7. See 'Pressestimmen', http://www.diefremde.de/. Accessed December 30, 2013.

8. Cf. also Berghahn: '[A] predilection for claustrophobic interiors and the use of locations on the peripheries of global cities [...] underscores the fact that social marginalization is still experienced by many migrant and diasporic subjects' $(2011,243)$.

9. Tarr has pointed out how female independence often comes in the shape of work in the lowpaid service sector, in canteens or restaurants, which can destabilize 'the conventional distribution of gender roles and challenge traditional, patriarchal, diasporic discourses on women's place within the community' $(2010,193)$.

10. Farzanefar draws attention to the power of silence and its ability to establish belonging to or exclusion from a community $(2010,9)$.

11. While there are heroines who 'forcefully counteract dominant imagery of migrant and diasporic women as passive victims, constructing strong, active female subjects whose largely homosocial affective ties enable them to forge visions of changing transnational, multicultural communities' (Tarr 2010, 193), namely, female characters like Gül and Atife, this is not their story.

12. According to Gramling, by engaging mythical structures, When We Leave conveys the message that Muslim women are never and nowhere safe from violence $(2012,36)$.

13. The political dimension of such stereotyping in artistic renditions, as well as the fine line between critiquing and reinforcing stereotypes, is summarized by Naficy:

That the $[\ldots]$ films that critique the homeland's traditions seem to get funded and distributed more readily raises the troubling specter of politically motivated film funding - even by organizations that are sympathetic to minoritarian values and practices. For example, it can be argued that while [the] representation of Muslim women as victims and of Muslim men as patriarchal overlords in these [...] films reflects and critiques the real gender relations among Turkish émigrés, it also corroborates the West's jaundiced view of Islam and of Muslims. (2001, 196)

\section{Notes on contributor}

Dr Cordula Böcking is a lecturer in the Department of German, School of Modern Languages, Literatures and Cultures, Maynooth University. Her research is concerned with aspects of gender and alterity, as well as myth reception, intercultural transmission of ideas and canon formation. She has co-edited Sexual-Textual Border-Crossings: Lesbian Identity in German-Language Literature, Film and Culture (2010) and is currently working on a project examining the link between transgressive femininity and cultural otherness in Middle High German epic and romance, which has to date resulted in several articles on medieval appropriations of the Amazon myth. More recently, she has become interested in constructions of the Orient and Occident in both medieval literature and contemporary text and film. 


\section{References}

Aladağ, Feo. 2010. "Interview mit Feo Aladag." Accessed December 30, 2013. http://www.die fremde.de/.

Berghahn, Daniela, and Claudia Sternberg. 2010. "Locating Migrant and Diasporic Cinema in Contemporary Europe." In European Cinema in Motion: Migrant and Diasporic Film in Contemporary Europe, edited by Daniela Berghahn and Claudia Sternberg, 12-49. Basingstoke: Palgrave Macmillan.

Berghahn, Daniela. 2010. “The Diasporic Youth Film and Questions of Genre." In European Cinema in Motion: Migrant and Diasporic Film in Contemporary Europe, edited by Daniela Berghahn and Claudia Sternberg, 235-255. Basingstoke: Palgrave Macmillan.

Berghahn, Daniela. 2011. “'Seeing Everything with Different Eyes': The Diasporic Optic of Fatih Akin's Head-On (2004)." In New Directions in German Cinema, edited by Paul Cooke and Chris Homewood, 239-256. London: I.B. Tauris.

Berghahn, Daniela. 2013. Far-Flung Families in Film. Edinburgh: Edinburgh University Press.

Buss, Christian. "Ehrenmord-Drama 'Die Fremde': Schrecken, ganz ohne Schleier." Der Spiegel. Accessed December 30, 2013. http://www.spiegel.de/kultur/kino/ehrenmord-drama-die-fremdeschrecken-ganz-ohne-schleier-a-682504.html.

Ewing, Katherine Pratt. 2006. "Between Cinema and Social Work: Diasporic Turkish Women and the Displeasures of Hybridity." Cultural Anthropology 21 (2): 265-294.

Ewing, Katherine Pratt. 2008. Stolen Honor: Stigmatizing Muslim Men in Berlin. Stanford, CA: Stanford University Press.

Farzanefar, Amin. 2010. Filmheft. Die Fremde. Feo Aladag. Deutschland 2010. Bonn: Bundeszentrale für Politische Bildung.

Göktürk, Deniz. 2000. "Turkish Women on German Streets: Closure and Exposure in Transnational Cinema." In Space in European Cinema, edited by Myrto Konstantarakos, 64-76. Exeter: Intellect.

Gramling, David. 2012. "The Oblivion of Influence: Mythical Realism in Feo Aladağ's Die Fremde (2010)." In Turkish German Cinema in the New Millennium: Site, Sounds, and Screens, edited by Sabine Hake and Barbara Mennel, 32-43. Oxford: Berghahn.

Hake, Sabine, and Barbara Mennel. 2012. "Introduction." In Turkish German Cinema in the New Millennium: Site, Sounds, and Screens, edited by Sabine Hake and Barbara Mennel, 1-16. Oxford: Berghahn.

Horrocks, David, and Eva Kolinsky. 1996. "Living and Writing in Germany: Emine Sevgi Özdamar in Conversation with David Horrocks and Eva Kolinsky." In Turkish Culture in German Society Today, edited by David Horrocks and Eva Kolinsky, 45-54. Providence, RI: Berghahn.

Huggan, Graham. 2001. The Postcolonial Exotic: Marketing the Margins. London: Routledge.

Laviosa, Flavia. 2010. "'Death is the Fairest Cover for Her Shame': Framing Honor Killings.” In Visions of Struggle in Women's Filmmaking in the Mediterranean, edited by Flavia Laviosa, 185-212. New York: Palgrave Macmillan.

Morgan-Tamosunas, Rikki, and Guido Rings. 2003. "Introduction." In European Cinema: Inside Out: Images of the Self and the Other in Postcolonial European Film, edited by Guido Rings and Rikki Morgan-Tamosunas, 11-23. Heidelberg: Winter.

Naficy, Hamid. 2001. An Accented Cinema. Princeton, NJ: Princeton University Press.

Özdamar, Emine Sevgi. 1998. Die Brücke von Goldenen Horn. Cologne: Kiepenheuer \& Witsch.

Said, Edward. (1975) 1995. Orientalism: Western Conceptions of the Orient. London: Penguin.

Tarr, Carrie. 2010. "Gendering Diaspora: The Work of Diasporic Women Film-Makers in Western Europe." In European Cinema in Motion: Migrant and Diasporic Film in Contemporary Europe, edited by Daniela Berghahn and Claudia Sternberg, 175-195. Basingstoke: Palgrave Macmillan.

Yaren, Özgür. 2011. "Die Fremde: European Space and Women Victims in Migrant Film." Kosmorama 247: 55-64. 